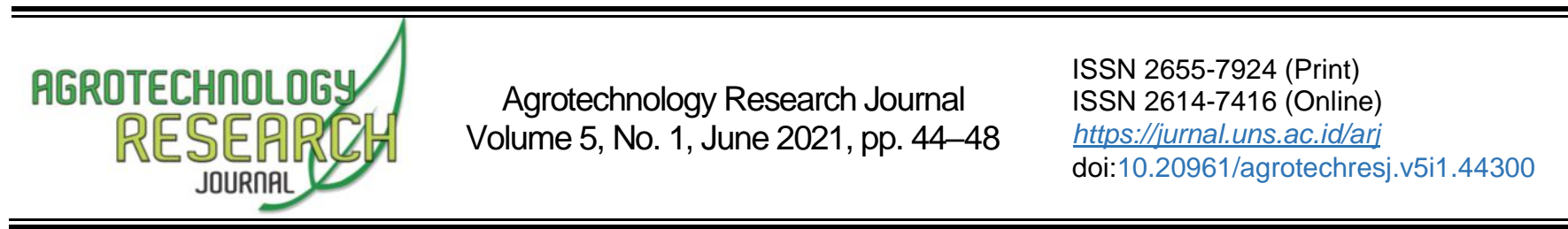

\title{
Pengaruh Pupuk Organik dan Plant Growth Promoting Rhizobacteria terhadap Pertumbuhan dan Hasil Kedelai
}

\section{Effects of Organic Fertilizer and Plant Growth Promoting Rhizobacteria on Soybean Growth and Yield}

\author{
Fajar Setyawan ${ }^{1 *}$, M. Machfud Aldi', Abu Talkah ${ }^{3}$ \\ ${ }^{1-3}$ Department of Agrotechnology, Faculty of Agriculture, Universitas Islam Kadiri, Kediri, Jawa Timur, 64128, Indonesia
}

Received 11 September 2020; Accepted 27 May 2021; Published 30 June 2021

\begin{abstract}
Nutrient availability is very significant in supporting plant growth. The low content of organic fertilizers and existing minerals appear as the primary limiting factors for soybean cultivation on acid soils. Therefore, the purpose of this research is to determine the effect of organic fertilizers and Plant Growth Promoting Rhizobacteria (PGPR) on plant growth and yield. A completely randomized block design (CRBD) factorial with three replications was employed, where the first variable involved the chicken and cow composts as well as Tithonia green fertilizer. Meanwhile, the second referred to PGPR at $0,5,10$ and $15 \mathrm{ml}^{-L^{-1}}$. The results showed no interaction between the application of organic fertilizers and PGPR on soybean growth as well as the yield. Furthermore, the cow manure treatment of 10 t.ha ${ }^{-1}$ reportedly increased the total dry weight and sample growth rate by 0.44 and $0.86 \%$, respectively, compared to the chicken manure at similar composition. Also, $10 \mathrm{ml}^{-\mathrm{L}^{-1}}$ of PGPR was known to improve the pod quantity per plant and harvest index by 0.58 and $2.66 \%$ harvest index, correspondingly, than without PGPR.
\end{abstract}

Keywords: Chicken manure; Cow manure; Glycine max; Tithonia

Cite this as (CSE Style): Setyawan F, Aldi MM, Talkah A. 2021. Pengaruh pupuk organik dan Plant Growth Promoting Rhizobacteria terhadap pertumbuhan dan hasil kedelai. Agrotechnology Res J. 5(1): 44-48. https://dx.doi.org/10.20961/agrotechresj.v5i1.44300.

\section{PENDAHULUAN}

Kedelai adalah tanaman pangan yang paling penting di Indonesia setelah padi dan jagung. Kedelai juga merupakan tanaman yang sumber protein nabatinya di perlukan untuk memenuhi kebutuhan gizi masyarakat Indonesia. Indonesia merupakan negara produsen tempe terbesar di dunia dan menjadi pasar kedelai terbesar di Asia (Kementerian Pertanian 2018; BPS 2020). Kebutuhan kedelai dari tahun ke tahun terus meningkat. Kedelai selama ini memang menjadi persoalan. Selain luas terbatas, produktivitas kedelai juga rendah. produksi dan kebutuhan pangan pokok tahun 2018 dari Kementerian Pertanian, produksi kedelai tahun 2018 sebesar 983 ribu (BPS 2020). Data konsumsi kedelai pada tahun 2018 kebutuhan kedelai sebesar 2224,1 ribu ton, sehingga defisit sebesar 1241,1 ton. Data tersebut menunjukkan bahwa produksi kedelai Indonesia belum memenuhi kebutuhan. Salah satu penyebabnya yaitu kualitas lahan yang semakin menurun karena penggunaan pupuk kimia yang semakin meningkat. Upaya yang dapat dilakukan untuk

\section{*Corresponding Author:}

E-Mail: fajar_setyawan26@yahoo.com meningkatkan kualitas lahan yaitu dengan penggunaan pupuk organik.

Penggunaan pupuk organik dalam jangka panjang dapat meningkatkan produktivitas lahan (Kwesiga et al. 2020). Bahan organik tanah berperan penting dalam meningkatkan dan mempertahankan kesuburan tanah, yang akan menentukan produktivitas tanaman dan keberlanjutan lahan pertanian (Muzaiyanah dan Subandi 2016; Pirttilä et al. 2021). Salah satu pupuk organik dari Tithonia dapat meningkatkan produktivitas jagung dan mengurangi jumlah gulma (Laude et al. 2021), selain itu pupuk Tithonia dapat mengubah sifat kimia tanah yaitu dapat meningkatkan $\mathrm{pH}$ tanah, C-organik, $\mathrm{N}$-total, $\mathrm{K}$ yang dapat ditukar, $\mathrm{Ca}$ yang dapat ditukar, $\mathrm{Mg}$ yang dapat ditukar (Enita et al. 2020; Puteri et al. 2021). Pertanian berkelanjutan dapat dilakukan dengan sistem budidaya dengan penggunaan pupuk organik dan peningkatan aktivitas mikroorganisme yang dapat dilakukan dengan penambahan Plant Growth Promoting Rhizobacteria (PGPR) (Mohamed et al. 2019; Zandi dan Basu, 2016). Pupuk organik dan PGPR dapat digunakan sebagai pupuk hayati karena dapat menghasilkan enzim yang larut, dan dapat sebagai agens pelarut mineral, agens biokontrol, dan fungisida biologis (Hafez et al. 2021; Moncada et al. 2020).

Salah satu mikroorganisme PGPR yang berfungsi untuk menyuplai hormon tumbuh seperti auksin, IAA dan 
giberelin yang diproduksi pada kondisi tertentu. Auksin berfungsi memacu pembentukan akar dan rambutrambut akar (Bouzroud et al. 2020; Erfin et al. 2016). Bahan organik berperan sebagai sumber energi dan makanan mikroorganisme PGPR sehingga dapat meningkatkan aktivitas mikroorganisme tersebut dalam penyediaan hara tanaman (Muliandari et al. 2018; Sari dan Sudiarso 2018). Pemberian pupuk organik dikombinasikan dengan PGPR diharapkan mampu menyediakan unsur hara. Kebaharuan dari penelitian menggunakan beberapa pupuk organik yang dikombinasikan dengan PGPR dalam mendukung hasil kedelai varietas Anjasmoro. Penelitian ini bermaksud untuk mendapatkan bahan organik yang sesuai jika di kombinasikan dengan PGPR. Berdasarkan uraian diatas maka penelitian ini bertujuan untuk mengetahui interaksi pupuk organik dan PGPR terhadap pertumbuhan dan produksi kedelai.

\section{BAHAN DAN METODE}

Penelitian dilaksanakan pada bulan November 2019 Februari 2020 bertempat di laboratorium lapang terpadu Universitas Islam Kadiri di desa Rejomulyo kecamatan kota Kediri. Tekstur tanah lempung berpasir dengan $\mathrm{pH}$ tanah 5,02, C- organik 2,51\% dengan ketinggian tempat 67 mdpl. Bahan yang digunakan terdiri dari benih kedelai varietas Anjasmoro, PGPR kepadatan 108cfu.mL-1 mengandung beberapa bakteri seperti Azotobacter sp., Azospirillium sp., Aspergillus sp., Pseudomonas sp., Bacillus sp. diperoleh dari Laboratorium Hama dan Penyakit Tumbuhan Universitas Brawijaya Malang. pupuk hijau paitan (kandungan kimia: C-organik: 35,45 $\%$, N: 2,51 \%, P: 0,48 \%, dan K: 0,99 \%), Pupuk kotoran sapi (kandungan kimia : C-organik: 18,79\%, N: 0,80\%, P: 0,24\%, dan K: 1,36 \%) dan Pupuk kotoran ayam (kandungan kimia : C-organik: 24,8\%, N: 2,15\%, P: 1,23 $\%$, dan K: 1,33 \%). Penelitian dirancang dengan Rancangan Acak Kelompok (RAK) pola faktorial terdiri dari dua faktor dan diulang sebanyak 3 kali. Faktor pertama: jenis pupuk organik $(P)$ yang terdiri dari: Pupuk kotoran ayam 10 t.ha $^{-1}$, Pupuk kotoran sapi 10 t.ha-1, $^{-1}$ Pupuk hijau paitan 10 t.ha $^{-1}$. Faktor kedua : PGPR yang terdiri dari: B0: Tanpa PGPR, B1: $\left(5 \mathrm{ml}^{-\mathrm{L}^{-1}}\right)$, B2: (10 ml.L1), B3: (15 ml. $\left.\mathrm{L}^{-1}\right)$. Petak penelitian dengan ukuran masing-masing $2 \mathrm{~m} \times 2,5 \mathrm{~m}$ sebanyak 36 petak. Pupuk kotoran sapi dan pupuk kotoran ayam didiamkan sampai tidak berbau dan sudah tidak berbentuk kotoran. Sedangkan pupuk hijau paitan diaplikasikan dalam bentuk daun segar. Aplikasi pupuk organik sesuai perlakuan sebagai pupuk dasar dengan aplikasi 2 minggu sebelum tanam, sedangkan aplikasi PGPR pada tanaman berumur 7, 21 dan 35 hari setelah tanam (HST) sesuai perlakuan. Penanaman dengan jarak tanam yang digunakan $25 \mathrm{~cm}$ x $25 \mathrm{~cm}$. Parameter Pertumbuhan yang diamati: Tinggi tanaman diamati 56 HST, Bobot kering total tanaman diamati $42 \mathrm{HST}$, laju pertumbuhan diamati 28-42 HST dengan Rumus

$$
\text { Laju Pertumbuhan }=\frac{W 2-W 1}{T 2-T 1} X \frac{1}{G A}
$$

dengan W1: bobot kering total tanaman pengamatan pertama (g); W2: bobot kering total tanaman pengamatan kedua (g); T1: waktu pengamatan pertama (hari); T2: waktu pengamatan kedua (hari); GA: luas lahan yang ternaungi $\left(\mathrm{m}^{2}\right)$. Parameter hasil yang diamati: Jumlah Polong per Tanaman dan Indeks Panen. Data yang diperoleh dianalisis dengan menggunakan analisis ragam (uji F) pada taraf $5 \%$ untuk mengetahui pengaruh perlakuan. Hasil analisis ragam yang nyata dilanjutkan dengan uji Beda Nyata Terkecil pada taraf nyata $5 \%$ untuk mengetahui perbedaan diantara perlakuan.

\section{HASIL DAN PEMBAHASAN \\ Pertumbuhan dan produksi kedelai}

Interaksi kedua faktor tersebut tidak berpengaruh nyata terhadap tinggi tanaman kedelai, bobot kering tanaman, laju pertumbuhan, jumlah polong per tanaman dan indeks panen (Tabel 1). Namun aplikasi pupuk organik berpengaruh nyata terhadap parameter pengamatan bobot kering tanaman dan laju pertumbuhan. Aplikasi PGPR berpengaruh nyata terhadap parameter jumlah polong per tanaman dan indeks panen.

Berdasarkan Tabel 1 tidak terdapat interaksi antara penggunaan pupuk organik dan PGPR terhadap tinggi tanaman pada berbagai umur pengamatan. Penggunaan pupuk organik pada semua pengamatan tidak terjadi pengaruh yang nyata terhadap parameter pengamatan tinggi tanaman kedelai. Hal ini disebabkan karena bakteri PGPR memiliki karakteristik yaitu harus mampu membentuk koloni pada permukaan tanah, sehingga secara langsung dapat membantu pertumbuhan tanaman dalam memperoleh sumber daya nitrogen, fosfor, dan mineral (Ali et al. 2020).

Penggunaan pupuk organik berpengaruh nyata terhadap parameter bobot kering tanaman dan laju pertumbuhan tanaman. Aplikasi pupuk organik dengan dosis optimum dapat menambah unsur hara esensial dan juga dapat meningkatkan ketersediaan unsur hara dalam tanah bagi tanaman kedelai (Sodiq et al. 2019). Pupuk kotoran sapi mengandung unsur N: 0,80\%, P: $0,24 \%$, dan $\mathrm{K}: 1,36 \%$ ). Unsur $\mathrm{N}$ yang berfungsi untuk perkembangan vegetatif tanaman. Bahan organik tanah berperan penting dalam meningkatkan dan mempertahankan kesuburan tanah, yang akan menentukan produktivitas tanaman dan keberlanjutan lahan untuk pertanian (Soltangheisi et al. 2021). Pupuk organik dari daun Gamal berpengaruh terhadap pertumbuhan dan produksi tanaman kedelai hitam mencapai 2,50 t.ha-1 (Ralle dan Subaedah 2020). Aplikasi Tithonia sebanyak 10 t.ha-1 dapat meningkatkan kandungan unsur hara tanah dibandingkan dengan tanpa Tithonia (Phiri et al. 2001). Hasil penelitian menunjukkan bahwa pupuk kotoran sapi berbeda nyata dengan pupuk kotoran ayam pada parameter laju pertumbuhan umur 28-42 HST (Tabel 1). Pupuk kotoran sapi memiliki kandungan: C-organik : $18,79 \%, \mathrm{~N}: 0,80 \%$, P : 0,24\%, dan K : 1,36\%. Lestari (2016) bahwa semakin cepat proses dekomposisinya semakin cepat unsur hara tersedia bagi tanaman. Tanah menjadi lebih remah dan pertukaran kation dan anion menjadi lebih cepat sehingga unsur hara yang diserap tanaman dengan baik menjadikan pertumbuhan tanaman baik (Crespo et al. 2011). Aplikasi bahan organik dan Bacillus subtilis dapat memberikan pengaruh terhadap pertumbuhan dan hasil tanaman, meningkatkan indeks panen sebesar 66,6 \% (Setyawan 2017). 
PGPR berpengaruh signifikan terhadap jumlah polong per tanaman dan indeks panen (Tabel 1). Hal ini disebabkan karena pembentukan polong sangat dipengaruhi oleh unsur K. Pupuk kotoran sapi pada penelitian ini memberikan hasil yang terbaik dengan kandungan unsur hara $\mathrm{K}: 1,36 \%$. Unsur kalium merupakan unsur hara penting untuk proses metabolisme protein, karbohidrat, lemak, dan transportasi karbohidrat dari daun ke akar. Kekurangan unsur $\mathrm{K}$ pada proses pembentukan polong dapat mengakibatkan penurunan jumlah polong dan bobot biji pertanaman (Hendrival et al. 2014; Swain et al. 2012). Hasil penelitian Swain et al. (2012) menunjukkan bahwa 5 strain bakteri Bacillus yang di isolasi dari bahan organik kotoran sapi mampu melarutkan fosfat anorganik menjadi $\mathrm{PO}_{4}^{3-}$ pada suhu $30^{\circ} \mathrm{C}$ sampai $50^{\circ} \mathrm{C}$. Phosfatase diekskresikan akar tanaman dan mikroorganisme, akan tetapi di dalam tanah fosfatase lebih dominan dihasilkan oleh mikroorganisme (Joner et al. 2000). Indeks panen yang berkisar antara $0,30-0,59$ dapat memberikan hasil biji yang tinggi (Gusnidar et al. 2010), sedangkan nilai indeks panen kurang dari 0,30 akan menghasilkan hasil biji yang rendah. Penggunaan PGPR memberikan pengaruh terhadap indeks panen tanaman kedelai (Tabel 1). Bakteri PGPR akan berkembang pada kondisi tanah tertentu dan faktor yang dapat memacu perkembangan populasi bakteri penambat $\mathrm{N}$ adalah ketersedian bahan organik, kondisi $\mathrm{pH}$ tanah dan tanaman inang yang sesuai (Tsukanova et al. 2017). Pupuk kotoran sapi berperan untuk meningkatkan kesuburan tanah melalui fungsinya sebagai penyedia nutrisi bagi Azotobacter sp. Tersedianya nutrisi bagi
Azotobacter sp. dapat membantu mengoptimalkan perannya dalam menjaga kesuburan tanah (Hafez et al. 2021).

Ketersediaan unsur hara bagi tanaman dapat mendukung pertumbuhan dan perkembangan tanaman semakin meningkat sehingga dapat meningkatkan hasil panen, Strain bakteri Alcaligenes, Burkholderia, Enterobacter, Pseudomonas, Bacillus, Aspergillus, Fusarium, Penicillium dan Rhizopus adalah bakteribakteri dari tanah dan rhizosfir yang paling efektif dalam melarutkan unsur hara P (Swain dan Ray 2009). Mikroorganisme membutuhkan bahan organik yang diambil dari lingkungan untuk mendukung siklus hidupnya. Bacillus, pseudomonas dapat meningkatkan pertumbuhan tanaman buncis, cluster bean, gandum, chick pea dan dapat digunakan sebagai biokontrol dan pelarutan P (Ahemad dan Kibret 2014; Suresh et al. 2021). Kemampuan biokontrol Bacillus substilis adalah kemampuan bakteri dalam melawan patogen (Compant et al. 2005). Aspergillus spp, merupakan salah satu jenis agens pengendali hayati yang telah dilaporkan mampu bersifat antagonis dan dapat mematikan serangga hama, Aspergillus spp, dilaporkan mampu bersifat patogen terhadap beberapa hama (Ratnadass 2020; Ratnadass et al. 2021), Bacillus sp merupakan bakteri gram positif yang memiliki endospora, Bacillus $\mathrm{sp}$ memiliki potensi mampu memproduksi IAA, melarutkan fosfat, mensekresi siderofor, dan berperan sebagai agens biokontrol dengan menginduksi sistem kekebalan tanaman serta menghasilkan antibiotik (Guo et al. 2017; Salehi et al. 2018; Adi et al. 2019; Bouzroud et al. 2020; Susilawati et al. 2020; Landberg et al. 2020).

Tabel 1. Pengaruh pupuk organik dan PGPR terhadap pertumbuhan dan hasil kedelai

\begin{tabular}{|c|c|c|c|c|c|}
\hline \multirow[b]{2}{*}{$\begin{array}{l}\text { Pupuk organik dan PGPR (dosis dan } \\
\text { kombinasinya) }\end{array}$} & \multicolumn{2}{|c|}{ Pertumbuhan Tanaman } & \multicolumn{3}{|c|}{ Hasil Tanaman } \\
\hline & $\begin{array}{l}\text { Tinggi } \\
\text { Tanaman } \\
\text { (cm) }\end{array}$ & $\begin{array}{c}\text { Bobot } \\
\text { Kering } \\
\text { Tanaman } \\
\text { (g) }\end{array}$ & $\begin{array}{c}\text { Laju } \\
\text { Pertumbuhan } \\
\left(\mathrm{g} \mathrm{m}^{-2} \text {.hari-1 }\right)\end{array}$ & $\begin{array}{l}\text { Jumlah } \\
\text { Polong Per } \\
\text { Tanaman }\end{array}$ & $\begin{array}{l}\text { Indeks } \\
\text { Panen }\end{array}$ \\
\hline P1: Pupuk Kotoran Ayam 10 t.ha $^{-1}$ & 51,68 & $3,07 \mathrm{a}$ & $1,48 \mathrm{a}$ & 31,7 & 0,05 \\
\hline P2: Pupuk Kotoran Sapi 10 t.ha-1 $^{-1}$ & 51,67 & $4,44 \mathrm{~b}$ & $2,76 \mathrm{~b}$ & 35,1 & 0,07 \\
\hline P3: Pupuk Hijau Paitan 10 t.ha $^{-1}$ & 50,17 & $3,62 a b$ & $2,27 \mathrm{ab}$ & 33,7 & 0,07 \\
\hline B0: Tanpa PGPR & 49,43 & 3,66 & 2,35 & $24,8 \mathrm{a}$ & $0,03 \mathrm{a}$ \\
\hline B1: PGPR ( $5 \mathrm{ml}^{-\mathrm{L}^{-1} \text { ) }}$ & 51,66 & 4,11 & 2,44 & $33,0 \mathrm{~b}$ & $0,06 \mathrm{a}$ \\
\hline B2: PGPR ( $\left.10 \mathrm{ml} \cdot \mathrm{L}^{-1}\right)$ & 52,37 & 4,09 & 2,41 & $39,2 \mathrm{~b}$ & $0,11 \mathrm{~b}$ \\
\hline B3: PGPR ( $\left.15 \mathrm{ml}^{\mathrm{L} \mathrm{L}^{-1}}\right)$ & 51,23 & 2,98 & 1,49 & $36,9 \mathrm{~b}$ & $0,05 a$ \\
\hline \multicolumn{6}{|l|}{ Interaksi PxB (tn) } \\
\hline P1B0 & 49,80 & 4,73 & 1,60 & 22,33 & 0,03 \\
\hline P1B1 & 54,12 & 4,74 & 1,49 & 31,67 & 0,05 \\
\hline P1B2 & 50,89 & 4,58 & 1,44 & 37,33 & 0,09 \\
\hline P1B3 & 51,89 & 4,35 & 1,37 & 35,33 & 0,04 \\
\hline P2B0 & 50,66 & 6,19 & 3,22 & 27,33 & 0,04 \\
\hline P2B1 & 50,43 & 5,16 & 2,25 & 32,33 & 0,05 \\
\hline P2B2 & 53,66 & 6,63 & 2,75 & 39,00 & 0,15 \\
\hline P2B3 & 51,94 & 6,73 & 3,87 & 38,67 & 0,04 \\
\hline P3B0 & 47,83 & 5,54 & 2,22 & 24,67 & 0,03 \\
\hline P3B1 & 50,44 & 5,60 & 3,57 & 35,00 & 0,08 \\
\hline P3B2 & 52,58 & 7,20 & 3,03 & 38,33 & 0,08 \\
\hline P3B3 & 49,85 & 5,33 & 2,23 & 36,67 & 0,07 \\
\hline
\end{tabular}

Keterangan: Angka - angka yang diikuti huruf yang sama pada kolom yang sama menunjukkan tidak berbeda nyata pada uji BNT 5\%. 


\section{KESIMPULAN}

Interaksi pupuk organik dan PGPR tidak berpengaruh nyata terhadap pertumbuhan tanaman dan hasil kedelai, Perlakuan pupuk kotoran sapi 10 t.ha ${ }^{-1}$ meningkatkan $0,44 \%$ bobot kering total tanaman pada umur dan 0,86 $\%$ pada laju pertumbuhan kedelai dibandingkan dengan pemberian pupuk kotoran ayam 10 t.ha $^{-1}$, Pada perlakuan PGPR 10 ml.L-1 meningkatkan $0,58 \%$ jumlah polong per tanaman dan 2,66 \% indeks panen.

\section{DAFTAR PUSTAKA}

Adi D, Elisabeth A, Mutmaidah S, Harsono A. 2019. Adoption determinants of biofertilizer technology for soybean in rainfed area adoption determinants of biofertilizer technology for soybean in rainfed area. IOP Conf Ser Earth Environ Sci. 347(012114):1-11. https://doi.org/10.1088/1755-1315/347/1/012114.

Ahemad M, Kibret M. 2014. Mechanisms and applications of plant growth promoting rhizobacteria: current perspective. J King Saud Univ - Sci. 26(1):120. http://dx.doi.org/10.1016/j.jksus.2013.05.001.

Ali S, Hameed S, Shahid M, Iqbal M, Lazarovits G, Imran A. 2020. Functional characterization of potential PGPR exhibiting broad-spectrum antifungal activity. Microbiol Res. 232:126389. https://doi.org/10.1016/j.micres.2019.126389.

Bouzroud S, Gasparini K, Hu G, Antonia M, Barbosa M, Rosa BL, Fahr M, Bendaou N, Bouzayen M, Zsögön A, et al. 2020. Down regulation and loss of auxin response factor 4 function using CRISPR/Cas9 alters plant growth, stomatal function and improves tomato tolerance to salinity and osmotic stress. Genes (Basel). 11(3):272. https://dx.doi.org/10.3390\%2Fgenes 11030272 .

[BPS] Badan Pusat Statistik. 2020. Produksi kedelai di Indonesia. Jakarta (ID): Badan Pusat Statistik.

Compant S, Duffy B, Nowak J, Clement C, Barka EA. 2005. Use of plant growth-promoting bacteria for biocontrol of plant diseases: principles, mechanisms of action, and future prospects. Appl Environ Microbiol. 71(9):4951-4959. https://doi.org/10.1128/aem.71.9.4951-4959.2005.

Crespo G, Ruiz TE, Alvarez J. 2011. Effect of green manure from Tithonia ( $T$. diversifolia) on the establishment and production of forage of $P$. purpureum cv. Cuba CT-169 and on some soil properties. Cuba J Agric Sci. 45(1):79-82.

Enita S, Sri WAS, Sri D. 2020. Pengaruh hidrogen peroksida dan ketersediaan air terhadap pertumbuhan vegetatif tanaman kedelai [Glycine max (L.) Merr.] varietas Deja 1. J IImu Pertanian. 32(1): 39-50

Erfin E, Sandiah N, Malesi L. 2016. Identifikasi bakteri azospirillum dan azotobacter pada rhizosfer asal komba-komba (Chromolaena odorata). J Ilmu dan Teknol Peternak Trop. 3(2):30-38. http://dx.doi.org/10.33772/jitro.v3i2.1684.

Guo Y, Jiang Q, Hu Z, Sun X, Fan S, Zhang H. 2017. Function of the auxin-responsive gene TaSAUR75 under salt and drought stress. Crop J. 6(2):181-190. https://doi.org/10.1016/j.cj.2017.08.005.
Gusnidar G, Hakim N, Prasetyo TB. 2010. Inkubasi titonia pada tanah sawah terhadap asam-asam $\begin{array}{llll}\text { organik. } & J & \text { Solum. }\end{array}$ https://dx.doi.org/10.25077/js.7.1.7-18.2010.

Hafez EM, Osman HS, El-razek UAA, Elbagory M. 2021. Foliar-applied potassium silicate coupled with plant physiology, nutrient uptake and productivity of faba $\begin{array}{lll}\text { bean. } & \text { 10(5):894. }\end{array}$ https://doi.org/10.3390/plants10050894.

Hendrival, Wirda Z, Azis A. 2014. Periode kritis tanaman kedelai terhadap persaingan gulma. J Floratek. $9(1): 6-13$.

Joner EJ, Van Aarle IM, Vosatka M. 2000. Phosphatase activity of extra-radical arbuscular mycorrhizal hyphae: a review. Plant Soil. 226(2):199-210. https://doi.org/10.1023/A:1026582207192.

Kementerian Pertanian. 2018. Outlook komoditas pertanian tanaman pangan Kedelai. Jakarta (ID): Pusat Data dan Sistem Informasi Pertanian Sekretariat Jenderal Kementerian Pertanian. 126 p.

Kwesiga J, Grotelüschen K, Senthilkumar K, Neuho D, Döring TF, Becker M. 2020. Effect of organic amendments on the productivity of rainfed lowland rice in the Kilombero floodplain of Tanzania. Agronomy. 10(9):1280. https://doi.org/10.3390/agronomy10091280.

Landberg K, Simura J, Ljung K, Sundberg E, Thelander M. 2020. Studies of moss reproductive development indicate that auxin biosynthesis in apical stem cells may constitute an ancestral function for focal growth control. New Phytol. 229(2): 845-860. https://dx.doi.org/10.1111/nph.16914.

Laude S, Mahfudz, Fathurrahman, Samuddin S, Rahim A, Darwis. 2021. Effect of atrazine and green fertilizer (Tithonia diversifolia) on weed growth and corn productivity. Earth Environ Sci. 681:012044. https://dx.doi.org/10.1088/1755-1315/681/1/012044.

Lestari SAD. 2016. Pemanfaatan paitan (Tithonia diversifolia) sebagai pupuk organik pada tanaman kedelai. Iptek Tanam Pangan. 11(1):49-55.

Mohamed I, Eid KE, Abbas MHH, Salem AA, Ahmed N, Ali M, Mustafa G, Fang C. 2019. Use of plant growth promoting Rhizobacteria (PGPR) and mycorrhizae to improve the growth and nutrient utilization of common bean in a soil infected with white rot fungi. Ecotoxicol Environ Saf. 171:539-548. https://doi.org/10.1016/j.ecoenv.2018.12.100.

Moncada FEL, AM Torres, DR Haro. 2020. GABA $A$ receptors are selectively expressed in NG2 glia of the cerebellar white matter. J Neuroscience. 433: 132-143. https://doi.org/10.1016/j. neuroscience.2020.03.003.

Muliandari N, Setiawan A, Sudiarso. 2018. Pengaruh aplikasi pupuk kandang kambing dan PGPR (Plant Growth Promoting Rhizobacteria) pada pertumbuhan dan hasil tanaman edamame (Glycine max (L.) Merrill). J Produksi Tanam. 6(10):2687-2695.

Muzaiyanah S, Subandi S. 2016. Peranan bahan organik dalam peningkatan produksi kedelai dan ubi kayu pada lahan kering masam. Iptek Tanam Pangan. 11(2):149-157. 
Phiri S, Barrios E, Rao IM, Singh BR. 2001. Changes in soil organic matter and phosphorus fractions under planted fallows and a crop rotation system on a Colombian volcanic-ash soil. Plant Soil. 231(2):211223. https://doi.org/10.1023/A:1010310300067.

Pirttilä AM, Mohammad H, Tabas P, Baruah N, Koskimäki JJ. 2021. Biofertilizers and biocontrol agents for agriculture: how to identify and develop new potent microbial strains and traits. Microorg Rev. 9(4):817. https://doi.org/10.3390/microorganisms9040817.

Puteri AR, Setyowati N, Fahrurrozi, Muktamar Z. 2021. Growth and yield of sweet corn (Zea mays L. Saccharata) as affected by incubation time of preparation for tithonia (Tithonia diversifolia) enriched liquid organic fertilizer. IOP Conf Ser Earth Environ Sci. 637:012090. https://doi.org/10.1088/1755-1315/637/1/012090.

Ralle A, Subaedah S. 2020. Respon kedelai hitam terhadap berbagai jenis pupuk organik. Agrotechnology Res J. 4(1):54-58. https://dx.doi.org/10.20961/agrotechresj.v4i1.36430.

Ratnadass A. 2020. Three-way interactions between crop plants, phytopathogenic fungi, and mirid bugs. A review. Agron Sustain Dev. 40:1-14. https://doi.org/10.1007/s13593-020-00652-1.

Ratnadass A, Avelino J, Fernandes P, Letourmy P, Babin R, Debert P, Deguine J, Grechi I, Naudin K, Rhino B, et al. 2021. Synergies and tradeoffs in natural regulation of crop pests and diseases under plant species diversification. Crop Prot 146. 146:115. https://dx.doi.org/10.1016/j.cropro.2021.105658.

Salehi B, Mishra AP, Shukla I, Sharifi-Rad M, Contreras $M$ del M, Segura-Carretero A, Fathi H, Nasrabadi NN, Kobarfard F, Sharifi-Rad J. 2018. Thymol, thyme, and other plant sources: health and potential uses. Phyther Res. 32(9):1688-1706. https://dx.doi.org/10.1002/ptr.6109.

Sari DN, Sudiarso. 2018. Aplikasi pupuk kandang ayam dan PGPR (Plant Growth Promoting Rhizobacteria) pada pertumbuhan dan hasil tanaman kedelai (Glycine max (L,) Merril). J Produksi Tanam. 6(10):2579-2587.
Setyawan F. 2017. Pengaruh bacillus subtilis dan bahan organik terhadap pertumbuhan dan produksi tanaman kedelai (Glycine Max L.). J Ilm Hijau Cendekia. 2(1):21-28.

Sodiq AH, Setiawati MR, Santosa DA, Widayat D. 2019. The potency of bio-organic fertilizer containing local microorganism of Cibodas village, Lembang-West Java. IOP Conf Ser Earth Environ Sci Pap. 383:012001. https://dx.doi.org/10.1088/1755-1315/383/1/012001.

Soltangheisi A, Haygarth PM, Pavinato PS, Paula A, Cherubin MR, Teles APB, Bordonal R, Carvalho JLN, Withers PJA, Martinelli LA. 2021. Long term sugarcane straw removal affects soil phosphorus dynamics. Soil Tillage Res. 208:1-8. https://dx.doi.org/10.1016/j.still.2020.104898.

Suresh P, Vellasamy S, Almaary KS, Dawoud TM, Elbadawi YB. 2021. Fluorescent pseudomonads (FPs) as a potential biocontrol and plant growth promoting agent associated with tomato rhizosphere. J King Saud Univ - Sci. 33(4):101423. https://doi.org/10.1016/j.jksus.2021.101423.

Susilawati A, Maftuah E, Fahmi A. 2020. The utilization of agricultural waste as biochar for optimizing swampland: a review The utilization of agricultural waste as biochar for optimizing swampland : a review. IOP Conf Ser Mater Sci Eng. 980:012065. https://dx.doi.org/10.1088/1757-899X/980/1/012065.

Swain MR, Laxminarayana K, Ray RC. 2012. Phosphorus solubilization by thermotolerant Bacillus subtilis isolated from cow dung microflora. Agric Res. 1(3):273-279. https://dx.doi.org/10.1007/s40003-012-0022-x.

Swain MR, Ray RC. 2009. Biocontrol and other beneficial activities of Bacillus subtilis isolated from cowdung microflora. Microbiol Res. 164(2):121-130. https://dx.doi.org/10.1016/j.micres.2006.10.009.

Tsukanova KA, C VK, Meyer JJM, Bibikova TN. 2017. Effect of plant growth-promoting Rhizobacteria on plant hormone homeostasis. South African J Bot. 113:91102. https://dx.doi.org/10.1016/j.sajb.2017.07.007.

Zandi P, SK Basu. 2016. Role of Plant Growth-Promoting Rhizobacteria (PGPR) as biofertilizers in stabilizing agricultural ecosystems. In: Nandwani D. Organic farming for sustainable agriculture. $(\mathrm{CH})$ : Springer International Publishing Switzerland. pp. 1-17. 